IZA DP No. 9519

Status Concern and Relative Deprivation in China: Measures, Empirical Evidence, and Economic and Policy Implications

Xi Chen

November 2015 


\title{
Status Concern and Relative Deprivation in China: Measures, Empirical Evidence, and Economic and Policy Implications
}

\author{
Xi Chen \\ Yale University \\ and IZA
}

Discussion Paper No. 9519

November 2015

\author{
IZA \\ P.O. Box 7240 \\ 53072 Bonn \\ Germany \\ Phone: +49-228-3894-0 \\ Fax: +49-228-3894-180 \\ E-mail: iza@iza.org
}

\begin{abstract}
Any opinions expressed here are those of the author(s) and not those of IZA. Research published in this series may include views on policy, but the institute itself takes no institutional policy positions. The IZA research network is committed to the IZA Guiding Principles of Research Integrity.

The Institute for the Study of Labor (IZA) in Bonn is a local and virtual international research center and a place of communication between science, politics and business. IZA is an independent nonprofit organization supported by Deutsche Post Foundation. The center is associated with the University of Bonn and offers a stimulating research environment through its international network, workshops and conferences, data service, project support, research visits and doctoral program. IZA engages in (i) original and internationally competitive research in all fields of labor economics, (ii) development of policy concepts, and (iii) dissemination of research results and concepts to the interested public.
\end{abstract}

IZA Discussion Papers often represent preliminary work and are circulated to encourage discussion. Citation of such a paper should account for its provisional character. A revised version may be available directly from the author. 
IZA Discussion Paper No. 9519

November 2015

\section{ABSTRACT}

\section{Status Concern and Relative Deprivation in China: Measures, Empirical Evidence, and Economic and Policy Implications ${ }^{1}$}

Status concern and the feelings of relative deprivation affect individual behavior and wellbeing. Traditional norms and the alarming inequality in China have made relative deprivation more and more intense for the Chinese population. This paper reviews empirical literature on China that attempts to test the relative deprivation hypothesis. We review the origins and pathways of relative deprivation, compare its economic measures in the literature, and summarize their applications. Drawing from solid empirical evidence, we discuss important policy implications on redistribution, official regulations and grassroots sanctions, and relative poverty alleviation.

JEL Classification: I14, I18, I32, B41

Keywords: inequality, status concern, relative deprivation, well-being, China

Corresponding author:

Xi Chen

School of Public Health and Department of Economics

Yale University

New Haven, CT 06520

USA

E-mail: xi.chen@yale.edu

1 The author appreciates the editors and two anonymous referees for very helpful suggestions. Financial support from the NIH/NIA (Grant Number 1 R03 AG048920-01) and Yale School of Public Health are gratefully acknowledged. 


\section{Introduction}

The quest for social status has been documented since the earliest writings known to humanity. As manifest in Hobbes's assertion that men are continually in competition for honor and dignity, concern for status became a central theme in Western political philosophy well before the birth of economics. The idea was later echoed by Adam Smith in The Wealth of Nations in $1776^{2}$ and then by Veblen ${ }^{3}$, Duesenberry ${ }^{4}$, among others. However, until relatively recently, an overwhelmingly majority of economic studies on rational choice theory and its applications assumed that the ultimate objects of desire for human beings are the absolute amount of individually consumed goods. This assumption stands in sharp contrast to how sociologists, psychologists, and researchers in other closely related disciplines view preferences for status. Fortunately, recent decades have witnessed a growing body of economic studies, both theoretical and empirical, that incorporate status into the research framework.

Features of status may determine relative deprivation and its fundamental influences over individual behavior and well-being. First, status is inherently relative, its value depends strongly on how it compares to others in the reference group. All parties in the equilibrium of status competition tend to divert resources away from welfare-enhancing basic goods and spend too much on positional goods in their efforts to win a zero-sum game, which may cause severe misallocation of resources, such as rent-seeking, wasteful overproduction and consumption, and environmental damage. Second, status often carries the expectation of entitlement to certain resources. Therefore, individuals are willing to sacrifice resources to obtain it. Third, status is sometimes non-tradable as an individual's ability to change status can be limited, especially in countries with high inequality or rigid social hierarchy. The resulting inefficiencies could be manifest in status markets through socially visible actions.

\footnotetext{
${ }^{2}$ Adam Smith (1776, Book 5, Chapter 2, Article 4) documents the role of a linen shirt in eighteenth century Europe: "A linen shirt, for example, is, strictly speaking, not a necessary of life. The Greeks and Romans lived, I suppose, very comfortably though they had no linen. But in the present times, through the greater part of Europe, a creditable day-labourer would be ashamed to appear in public without a linen shirt, the want of which would be supposed to denote that disgraceful degree of poverty which, it is presumed, nobody can well fall into without extreme bad conduct."

${ }^{3}$ Veblen, Thorstein. The Theory of the Leisure Class. (New York: MacMillan, 1899, Reprint 1965).

${ }^{4}$ Duesenberry, J.S. Income, Saving and the Theory of Consumer Behavior. (Cambridge, MA: Harvard University Press, 1949).
} 
Distinguished from the negative effects generated by lower absolute income or higher inequality per se, those who are of lower status (or relatively poor) suffer from an additional effect of relative deprivation (hereafter RD). Formally conceptualized by Runciman, ${ }^{5} \mathrm{RD}$ refers to the discontent people feel when they compare their positions to others and realize that others in the group possess something that they do not have. Motivated by RD, the relatively poor may feel more stressed, be less happy, and be more susceptible to diseases. They may give up some real benefits for the sake of improving status.

This paper discusses origins, potential pathways, and economic measures of RD in the literature. ${ }^{6}$ Empirical studies applying these measures to identify the effects of status concern and $\mathrm{RD}$ on a wide range of economic behaviors and on objective and subjective well-being are reviewed. We finally discuss important implications for policies on taxation and poverty alleviation, as well as official regulations and grassroots sanctions.

The review is restricted to status concern and RD in China, the second largest economy in the world, where status disparities have been one of the most pressing issues. China's strategy of "let some people get rich first" has resulted in extremely uneven growth during the last three decades of economic reform accompanied by worsening inequality. There are mounting concerns that this growing inequality hinders sharing of the fruits of economic development. In addition, the social unrest that accompanies worsening inequality may slow down economic transition and hinder future growth. The most recent Gini coefficient has been alarmingly high, ranging from the official figure ${ }^{7} 0.47$ to the grass-root survey figure ${ }^{8} 0.61$. The more noticeable status disparities are, the more concerned with status people become, and the more pronounced $\mathrm{RD}$ have-nots feel when compared with haves.

\footnotetext{
${ }^{5}$ Runciman, W.G. Relative Deprivation and Social Justice. Routledge and Kegan Paul, London, 1966.

${ }^{6}$ Relative deprivation is also known as relative poverty. In contrast to absolute deprivation (or absolute poverty) that applies to all underprivileged people, RD comes from a comparison to the reference group. While economic growth may be accompanied by massive absolute poverty reduction, $\mathrm{RD}$ may not change as long as inequality persists.

${ }^{7}$ Source: China National Bureau of Statistics, 2013.

${ }^{8}$ The survey was conducted by the Chinese Household Finance Survey Center, a body set up by the Finance Research Institute of the People's Bank of China and Southwestern University of Finance and Economics. http://www.chfsdata.org/
} 
Moreover, the issue of status concern has been culturally important to the Chinese population, as reflected in the traditional saying "it is better to be the head of a chicken than the tail of a phoenix", which suggests that people in Chinese society place high weight on relative position. A recent lab experiment comparing China with some other countries, including the U.S., Turkey, Germany and Finland, finds that Chinese tend to value status the most and independently of monetary consequences. ${ }^{9}$ In the labor market, employees often benefit less from absolute consumption but more from positional benefits as their income increases. Therefore, status concern and RD in China may provide employee incentives that benefit enterprises. For example, non-monetary symbols of status within enterprises, such as respect and attention paid by an employer and coworkers to employees, act as incentives to work and likely optimize enterprise benefits without incurring high financial costs. A survey-based experiment elicits peoples’ preferences regarding relative standing. ${ }^{10}$ They find that poor Chinese farmers care about relative status to a high degree, comparable to previous studies in developed countries. Asian consumers, perhaps because of the structures of their society, tend to be very status oriented. ${ }^{11}$

The paper is organized in five parts. Section 1 introduces the idea and main features of status concern and RD, and its economic and social importance in China. Section 2 reviews origins, pathways, comparison groups, and economic measures of RD in the literature. Section 3 summarizes Chinese studies on the impact of RD on economic behavior, happiness and health. Section 4 connects empirical findings to economic impacts and discusses the implications for improving public policies. Section 5 concludes and discusses remaining knowledge gaps in understanding RD and its multidimensionality.

\footnotetext{
${ }^{9}$ Huberman, Bernardo A., Christoph H. Loch, and Ayse Önçüler. Status as a Valued Resource. Social Psychology Quarterly. 67(1) (2004): 103-114.

${ }^{10}$ Carlsson, F. and P. Qin. It is better to be the head of a chicken than the tail of a phoenix: Concern for relative standing in rural China, The Journal of Socio-Economics. 39(2) (2010): 180-186.

${ }^{11}$ Ball, Sheryl B. and Catherine C. Eckel. Buying Status: Experimental Evidence on Status in Negotiation. Psychology and Marketing 13(4) (1996): 381-405.
} 


\section{Relative Deprivation: Origins, Pathways and Economic Measures}

Social status and RD have been defined along various socioeconomic distributions, such as general consumption relative to others ${ }^{12}$, status goods consumption relative to peers ${ }^{13}$, relative income ${ }^{14}{ }^{15} 16$, perceived economic welfare ${ }^{17}$ and subjective financial status ${ }^{18}$. Among them, measures of RD based on income are more widely used in empirical studies.

\subsection{Origins and Potential Pathways}

$\mathrm{RD}$ may originate from the nature of our human beings and the earliest society we lived in. Human well-being is maximized when we live under conditions that mimic those under which we evolved. The earliest hunter-gatherer society punished those who deviated from the practice of equal sharing of food, the most effective consumption smoothing arrangement given occasional killing of large animals and inability to store the meat. Therefore, our evolutionary history inclines us towards equality and sickens us when we live in unequal and relatively deprived environments. ${ }^{19}$ Moreover, rank, rather than money itself, may determine power and access to (exclusive) material goods. For example, higher ranked people in communities with limited land for housing tend to live in houses with better views, and occupational status may determine the degree of control people have over others.

Status concern and the feelings of RD are often associated with individual behavior and wellbeing through three channels. The first channel is absolute income. Low-status individuals may feel lack of purchasing power and resources for maintenance of life, which undermines the protective role of income. The second channel is income inequality. For individuals with a given level of absolute income, those living in more unequal societies are worse off. Higher inequality

\footnotetext{
${ }^{12}$ Easterlin, R. Income and happiness: towards a unified theory. Economic Journal 111 (2001): 465-484.

${ }^{13}$ Cooper, B., C. Garcia-Penalosa. and P. Funk. Status effects and negative utility growth. Economic Journal. 111 (2001): 642-665.

${ }^{14}$ Wildman, J. Modeling health, income and income inequality: The impact of income inequality on health and health inequality. Journal of Health Economics. 22 (2003a): 521-538.

${ }^{15}$ Deaton, A. Relative deprivation, inequality, and mortality. NBER Working Paper 8099, 2001.

${ }^{16}$ Yitzhaki, S. Relative deprivation and the Gini coefficient. Quarterly Journal of Economics. 93(2) (1979): 321-24.

${ }^{17}$ Ravallion, M. and M. Lokshin. Who cares about relative deprivation? Journal of Economic Behavior \& Organization. 73(2) (2010): 171-185.

${ }^{18}$ Wildman, J. Income related inequalities in mental health in Great Britain: Analyzing the causes of health inequality over time. Journal of Health Economics. 22 (2003b): 295-312.

${ }^{19}$ Deaton. Relative deprivation, inequality, and mortality.
} 
in and of itself is thus a potential threat to well-being. This channel indicates that inequality affects all members in a society equally, irrespective of their income levels. Only the third channel, i.e. the relative income effect, captures the real impact of status concern and feelings of $\mathrm{RD}$ on individual behavior and well-being. Through this channel, a given level of income inequality in a society may disproportionally affect those less well-off. In other words, income inequality affects individuals through channels dependent on their relative income status but independent of the inequality of the society they live in.

While the absolute income effect can be removed via controlling for absolute income level, studies using community level inequality measures, such as the widely accepted Gini coefficient $^{20} 21$, are unable to isolate the relative income effect from the income inequality effect. Subsequent studies interact Gini coefficient with income group indicators to capture some of the heterogeneous RD motives between groups. ${ }^{22}$ Other community measures, such as skewness and kurtosis statistics, attempt to identify heterogeneous impacts via certain features of the distribution. Specifically, skewness measures the relative asymmetry of income, and kurtosis measures the peakedness of the distribution. Both statistics are good measures of local density in tails of income distribution ${ }^{23}$. However, since status concern and the feelings of RD are heterogeneous along income distribution, individual level RD measures often perform better in capturing the effect.

\subsection{Measuring Relative Deprivation}

In the literature, status concern and feelings of RD are measured at the individual level to gauge the relative income effect. First, studies on non-human primates suggest rank surpasses distance in importance. ${ }^{24}$ Rank is largely unaffected by changes in the shape of income distribution.

\footnotetext{
${ }^{20} \mathrm{Li}, \mathrm{H}$. and Y. Zhu. Income, income inequality, and health: Evidence from China. Journal of Comparative Economics. 34(4) (2006): 668-693.

${ }^{21}$ Ling, D. Do the Chinese ‘keep up with the joneses’? Implications of growing economic disparities and relative deprivation on health outcomes among older adults in China. China Economic Review. 20(1) (2009): 65-81.

$22 \mathrm{Jin}, \mathrm{Y} ., \mathrm{Li}, \mathrm{H}$. and B. Wu. Income inequality, consumption, and social-status seeking. Journal of Comparative Economics 39 (2011): 191-204.

${ }^{23}$ Brown, P., E. Bulte. and X. Zhang. Positional spending and status seeking in rural China. Journal of Development Economics. 96(1) (2011): 139-149.

${ }^{24}$ Deaton. Relative deprivation, inequality, and mortality.
} 
Studies utilize individual's rank over incomes within the reference group. ${ }^{25} 26$ Second, controlling for own income, studies use average community income to identify the relative income effect. ${ }^{27} 28$ The larger the negative impact of community income, the more relatively deprived one feels.

Third, some individual RD measures presume that the distance between two agents matters, either in proportional or absolute terms. They incorporate the idea of asymmetry in social comparisons, because people tend to make upward rather than downward social comparisons $^{29}{ }^{30}$, and a recent study finds insignificant role of downward comparisons but positive and significant role for upward comparisons in China. ${ }^{31}$ Specifically, a set of measures gauge individual RD via the differences between an individual's income $\left(y_{i}\right)$ and the incomes of the richer members of the group $\left(y_{j}\right)$. These measures also allow one to feel more deprived as the number of individuals in society with higher income increases.

The first such measure, also known as RD of absolute income (RDA), is defined by summing the income differences and weighing it with the number of people in a reference group. One concern about RDA is that it does not take into account differences in the scale of income across reference groups at one point of time or within group over time. For example, RDA doubles if everyone’s income doubles. RDA overstates individuals’ RD in high-income reference groups. To improve this measure, RD over individual income (RDI) is defined as the ratio of RDA relative to the individual's own income $\left(y_{i}\right){ }^{32}$

\footnotetext{
${ }^{25} \mathrm{Li}$ and Zhu. Income, income inequality, and health. 668-693.

${ }^{26}$ Sun, W. and X. Wang. Do relative income and income inequality affect consumption? Evidence from the villages of rural China. Journal of Development Studies. (2012): 1-14.

${ }^{27}$ Carlsson and Qin. It is better to be the head of a chicken than the tail of a phoenix. 180-186.

${ }^{28}$ Mangyo, E. and A. Park. Relative deprivation and health: Which reference groups matter? Journal of Human Resources 46(3) (2011): 459-481.

${ }^{29}$ Duesenberry. Income, Saving and the Theory of Consumer Behavior.

${ }^{30}$ Frank R.H. The demand for unobservable and other non-positional goods. American Economic Review 75 (1985): 101- 116.

${ }^{31}$ Tao, H. and Chiu, S. The effects of relative income and absolute income on happiness. Review of Development Economics 13(1) (2009): 164-174.

${ }^{32} \mathrm{Li}$ and Zhu. Income, income inequality, and health. 668-693.
} 


$$
\begin{gathered}
R D A_{i}=\frac{1}{N_{i}} \sum_{j}\left(y_{j}-y_{i}\right) \quad \forall y_{j}>y_{i} \\
R D I_{i}=R D A_{i} / y_{i}
\end{gathered}
$$

Intuitively following the measure of Gini coefficient as the ratio of the area between the Lorenz curve and the line for uniform distribution to the area below uniform distribution line, a measure $d_{y_{i}}(F)$ of individual-specific RD incorporates the cumulative proportion of total income $F_{1}\left(y_{i}\right)$ and population $F\left(y_{i}\right)$ up to the individual $i$ with income $y_{i} \cdot{ }^{33} \mu$ denotes mean income.

$$
d_{y_{i}}(F)=\mu\left[1-F_{1}\left(y_{i}\right)\right]-y_{i}\left[1-F\left(y_{i}\right)\right]
$$

Observing the different patterns of migration for the richest group and the poorest group, a RD model is developed that simplifies Runciman's theory with appealing empirical applications and complements the utility-social welfare approach. ${ }^{34}$ The fact that this measure at the societal level is equal to the absolute Gini index (the Gini multiplied by the mean) implies that a society suffering from worse inequality also has higher overall RD. Moreover, holding the Gini index constant, increasing mean income over time also pushes up RD.

$$
\begin{gathered}
R D\left(y_{i}\right)_{\text {Yitzhaki }}=\int_{y_{i}}^{\bar{x}}[1-F(x)] d x \quad \text { (for continuous distribution) } \\
R D\left(y_{i}\right)_{\text {Yitzhaki }}=\left[1-F\left(y_{i}\right)\right] \cdot E\left(x-y_{i} \mid x>y_{i}\right) \quad \text { (for discrete distribution) }
\end{gathered}
$$

An independent literature proposes a now widely used measure of RD that integrates the model of mortality and income with the animal and human evidence on inequality and health. ${ }^{35}$ The two measures, the Stark-Yitzhaki measure and the Deaton measure, are very close to one another. The Deaton measure takes differences between the average income of richer counterparts in the reference group and this individual's income $y_{i}$, weighted by the proportion of those with

\footnotetext{
${ }^{33}$ Wildman, J. Income related inequalities in mental health in Great Britain. 295-312.

${ }^{34}$ Stark, O. and S. Yitzhaki. Labor migration as a response to relative deprivation. Journal of Population Economics. 1 (1) (1988): 57-70.

${ }^{35}$ Deaton. Relative deprivation, inequality, and mortality.
} 
income higher than the individual i. Compared with the Stark-Yitzhaki measure, the Deaton measure is further divided by average community income to normalize the RD index. Specifically, the Deaton RD measure for an individual $i$ with income $y_{i}$ can be expressed as

$$
\begin{gathered}
R D\left(y_{i}\right)_{\text {Deaton }}=(1 / \mu) \int_{y_{i}}^{\bar{x}}\left(x-y_{i}\right) d F(x) \quad \text { (for continuous distribution) } \\
R D\left(y_{i}\right)_{\text {Deaton }}=(1 / \mu)\left[1-F\left(y_{i}\right)\right]\left[\mu^{+}\left(y_{i}\right)-y_{i}\right] \quad \text { (for discrete distribution) }
\end{gathered}
$$

where $\mu$ denotes mean income in the reference group, $y_{i}$ denotes individual i's own income, $\bar{x}$ corresponds to the highest income in the group. $\mathrm{F}(\mathrm{x})$ is the cumulative distribution of income in the group, and $\mu^{+}\left(\mathrm{y}_{i}\right)$ is the average income of individual i's richer counterparts in the group.

Four immediate advantages of the Deaton RD index follow. First, a diverse body of scientific evidence, such as in the field of public health, psychology, animal science, economics, and so on, lays solid foundation for the index. ${ }^{36}$ Second, it considers the scale issue that may overestimate $\mathrm{RD}$ in high-income groups when incomes differ substantially across groups or when an individual's income saliently changes over time. Third, relative to some other RD indexes, such as RDI, the Deaton RD is more sensitive to income distribution. Fourth, the Deaton RD is bounded between 0 and 1 , which facilitates the interpretation of empirical findings.

\subsection{Reference Groups}

While the definition of the reference group is vital to all RD measures, localized knowledge is very rare in empirical studies. Therefore, the empirical literature is still in its infancy on this issue. ${ }^{37}$ First, due to psychological factors, individuals may have various approaches to choose reference groups, resulting in heterogeneity that is not easily captured in empirical studies.

Second, reference groups can be defined quite differently in different contexts. The reference group for the workplace can be quite different from that at home. Limited by specific datasets,

\footnotetext{
${ }^{36}$ For a comprehensive review of its multidisciplinary foundation, please refer to Deaton's 2001 NBER paper "Relative deprivation, inequality, and mortality".

${ }^{37}$ Clark, A.E., Frijters, P. and Shields, M. Relative income, happiness and utility: An explanation for the Easterlin paradox and other puzzles. Journal of Economic Literature 46(1) (2008): 95-144.
} 
few studies simultaneously consider all relevant reference groups, even though multiple reference groups may jointly determine well-being.

Third, selecting reference groups is less straightforward in modern societies, where information flow is fast and efficient, and individuals may move frequently during their lifetime. People in a traditional society, however, often interact in smaller and closer reference groups, as poor infrastructure slows information flow and the power of local norms strengthens reciprocity. These differences facilitate an improved definition of reference group in rural communities.

Substantial ethnographic evidence documents that reference groups are dependent on the village, rather than city blocks, census tracks, schools or classrooms, in less-developed rural communities. A recent study in economics also suggests that village reference groups are salient for residents living in close proximity in rural China, while relatives and classmates are salient reference groups for urban residents. ${ }^{38}$ In another recent study, 68 percent of survey respondents in China reported that their main comparison group consisted of individuals in their own village, which still leaves a third of the population who look for reference points outside their own villages. $^{39}$

\footnotetext{
${ }^{38}$ Mangyo and Park. Relative deprivation and health. 459-481.

${ }^{39}$ Knight, J., L. Song. and R. Gunatilaka. Subjective well-being and its determinants in rural China. China Economic Review. 20(4) (2009): 635-649.
} 


\section{Behavioral and Welfare Consequences of Relative Deprivation}

Status concern and the feelings of $\mathrm{RD}$ have been shown to affect both subjective and objective well-being. Subjective well-being measures the extent to which momentary well-being or general life satisfaction is achieved, while objective well-being gauges achievement in basic needs and rights. Happiness provides an example of subjective measures, and health status is an example of objective measures of well-being. These dimensions complement money metric measures, such as income per capita, as indicators of individual well-being. This section summarizes existing empirical evidence on health and happiness consequences of status concern and RD in China as well as behavior responses. Their sources of variation, utilized datasets and the identified magnitudes of RD are summarized in Table 1.

\subsection{Empirical evidence on happiness}

Generally, higher inequality leads to a less happy society given the standard assumption that status term in the utility function is concave. Studies on RD and happiness attempt to account for two seemingly contradicting trends (a.k.a. the Easterlin paradox): average happiness has remained constant over time despite sharp rises in income but, at the same time, positive correlations are found between individual income and measures of subjective well-being. This paradox applies to a large set of countries and puzzles policymaking in the world ${ }^{40}$, and China is no exception. ${ }^{41}$

$\mathrm{RD}$ provides a more plausible explanation for the Easterlin paradox than competing models do. ${ }^{42}$ $\mathrm{RD}$ may arise when one observes that others have acquired more positional goods ${ }^{43}$ or it may result from aspirations formed by relative comparisons. ${ }^{44}$ The former is evaluated relative to others (via social comparison), while the latter is evaluated relative to oneself in the past or future or relative to others (via social comparison). Studies confirm the negative role of RD on

\footnotetext{
${ }^{40}$ Easterlin, R. Does economic growth improve the human lot? Some empirical evidence. In Nations and Households in Economic Growth: Essays in Honor of Moses Abramovitz, ed. R. David and M. Reder. (New York: Academic Press, 1974), 89-125.

${ }^{41}$ Brockmann, H., Delhey, J., Christian, W. and Yuan, H. The China puzzle: Falling happiness in a rising economy. Journal of Happiness Studies 10(4) (2009): 387-405.

${ }^{42}$ Graham, C., S. Chattopadhyay, and M. Picon. "The Easterlin and other paradoxes: Why both sides of the debate may be correct.” In: Diener, E., J. F. Helliwell, and D. Kahneman (eds). International Differences in Well-Being (Positive Psychology) (Oxford: Oxford University Press, 2010), 247-290.

${ }^{43}$ Frank, R.H. Luxury Fever: Why Money Fails to Satisfy in an Era of Excess. (New York: Free Press, 1999).

${ }^{44}$ Easterlin. Income and happiness. 465-484.
} 
happiness for various groups of people in both urban and rural China 4546474849 . Though these studies suggest that higher absolute income enhances happiness, higher RD (due to a lower relative income) becomes more important than absolute income in explaining happiness in China, especially in richer contexts. ${ }^{50} 51$

\subsection{Empirical evidence on health}

Disparities in both income and health have increased in recent decades despite substantial gains in standards of living. Persistent RD undermines the protective role played by the biochemical system of stress response against a wide range of human diseases. ${ }^{52}$ Though some studies still find mixed results, more and more evidence seems to suggest negative impacts of status concern and $\mathrm{RD}$ on a range of health measures. These findings indicate the importance of monitoring public policies that may stimulate large income disparities that affect long-term health and health inequality.

Self-reported health status (SRHS), physical function, and activities of daily living (ADL) are nonlinearly associated with community-level income inequality. ${ }^{53}$ Specifically, the inverted-U shape relationship determines that a rising Gini coefficient tends to be harmful when the Gini index is above a certain level. Meanwhile, inequality increases the likelihood and frequency of health-compromising behavior such as smoking and alcohol consumption. Though lower individual rank corresponds to worsened health outcomes, the negative impacts of income inequality on SRHS, heart function, and ADL do not vary with relative income or rank. To the

\footnotetext{
${ }^{45}$ Knight, J. and Gunatilaka, R. Income, aspirations and the Hedonic Treadmill in a poor society. Journal of Economic Behavior \& Organization. 82(1) (2012): 67-81.

${ }^{46}$ Appleton, S. and Song, L. Life satisfaction in urban China: Components and Determinants. World Development 36 (2008): 2325-2340.

${ }^{47}$ Mangyo and Park. Relative deprivation and health. 459-481.

${ }^{48}$ Oshio, T, Nozaki, K. and Kobayashi, M. Relative Income and happiness in Asia: Evidence from nationwide surveys in China, Japan and Korea. Social Indicators Research 104 (2011): 351-367.

${ }^{49}$ Wang, P. and Vander Weele, T.J. Empirical Research on Factors Related to the Subjective Well-being of Chinese Urban Residents. Social Indicators Research 101 (2011): 447-459.

${ }^{50}$ Knight, Song, and Gunatilaka. Subjective well-being and its determinants in rural China. 635-649.

51 Tao and Chiu. The effects of relative income and absolute income on happiness. 164-174.

52 Wildman. Modeling health, income and income inequality. 521-538.

${ }^{53} \mathrm{Li}$ and Zhu. Income, income inequality, and health: Evidence from China. 668-693.
} 
contrary, community level inequality does not explain any of the health outcomes and health behavior investigated except probability of high waist circumference. ${ }^{54}$

Using the subjective rating of own income relative to peers average income and mean per capita income within the group, there is a negative impact of RD status on SRHS and psychosocial health. ${ }^{55}$ RDA, RDI, and rank are not significantly associated with SRHS, heart function and ADL in China. ${ }^{56}$

Using both Wildman and Deaton RD measures, among older adults in China feelings of RD have significant effects on health outcomes and health behavior, but this issue is complicated by the findings that being less economically deprived may not guarantee better health, and that those who are more economically deprived do not have worse health. Specifically, those with higher levels of RD have lower rates of high waist circumference, are less likely to be overweight, take more nutrients, and are less likely ever to smoke. However, their probability of being underweight, their rate of hypertension, and their current smoking behavior are not significantly affected. ${ }^{57}$ Further research is required to examine the absolute and relative income effects on health inequalities among the elderly, along with other major health behavior and outcomes.

RD may also have intergenerational health impacts. People who skip costly social festivals or who spend less than their richer counterparts lose face and risk becoming socially excluded. For that reason, many people at the bottom of the status and wealth distribution tend to attend no fewer ceremonies than their better-off peers and to give even more lavish gifts to signal a higher status. Thus, it is more burdensome for the poor to take part in these social occasions than for the rich. Because the poor often lack the necessary resources to finance these activities, they are often forced to skimp on food consumption to compensate. As a consequence of frequent exposures to lavish spending on festivals held by fellow villagers, children born to mothers in more relatively deprived households (measured by the household's long-term economic status

\footnotetext{
${ }^{54}$ Ling. Do the Chinese 'keep up with the joneses'? 65-81.

${ }^{55}$ Mangyo and Park. Relative deprivation and health. 459-481.

${ }^{56} \mathrm{Li}$ and Zhu. Income, income inequality, and health. 668-693.

${ }^{57}$ Ling. Do the Chinese 'keep up with the joneses'? 65-81.
} 
relative to that of her richer peers) are more likely to suffer from malnutrition indicated by low height-for-age z-score and stunting status. ${ }^{58} 59$

\subsection{Empirical evidence on behavior responses}

Rising income inequality and the feelings of RD strengthen the incentives to seek higher social status by increasing the benefit of improving status and enlarging the wealth level required for status upgrading. ${ }^{60}$ There has been accumulative evidence on behavior changes in response to status concern and RD amid worsening inequality. While in some cases status concern and feelings of RD may exert positive impacts on individual behavior, such as motivating those of lower status to work harder and migrate to better places ${ }^{61}$, their negative impacts on individual behavior often dominate, such as squeezing out basic consumption for the lower tail of the distribution.

Results indicate that income inequality has a negative (positive) impact on households’ overall consumption (savings) in urban China. ${ }^{62}$ Urban residents, especially the poorer group, save to improve their social status when social status is tied to pecuniary and non-pecuniary benefits. ${ }^{63}$ However, studies in rural China find that lower income rank and higher RD within a community promote total expenditure. The differences in overall consumption between urban and rural China may originate from very different inequality and RD measures (community level versus individual level) applied in these studies. Moreover, the differentiated impacts on consumption behavior may also depend on different economic development stages (between rural and urban China) that deserve further investigation. For sub-categories of consumption, one common finding for both urban and rural settings is that status concern and the feelings of RD stimulate

\footnotetext{
${ }^{58}$ Chen X. Fetus, Fasting, and Festival: The Persistent Effects of in Utero Social Shocks. International Journal of Health Policy and Management 3 (2014): 165-169.

${ }^{59}$ Chen, X. and X. Zhang. Costly posturing: relative status, ceremonies and early child development in China. World Institute for Development Economic Research (UNU-WIDER) Research Working Paper No. 2012/70.

${ }^{60}$ Chen X. Essays on Social Networks: Relative Concerns, Social Interactions, and Unintended Consequences. American Journal of Agricultural Economics 96 (2) (2014): 607-609.

${ }^{61}$ Cai, F., Du, Y. and M. Wang. The Political Economy of Labor Migration. (Shanghai: People's Press of Shanghai, 2003), 86-109.

62 Jin, Li and Wu. Income inequality, consumption, and social-status seeking. 191-204.

$63 \mathrm{Jin}, \mathrm{Li}$ and Wu. Income inequality, consumption, and social-status seeking. 191-204.
} 
more investment in education that may signal future status. Moreover, expenditures on housing, clothing and eating out increase as inequality and feelings of RD rise in rural China. ${ }^{64}$

Ceremonies, such as funerals and weddings, have been very important in Chinese society. Though low cost burials have been national policy, rich people tend to spend lavishly on large and ostentatious tombs that irk the poor. ${ }^{65}$ Disadvantaged males, especially in regions with skewed sex ratios that favor women, have to pour all their resources (to throw a luxury party, buy a house, pay a large bride price, etc.) as a means of signaling wealth and improving their chance of getting married. ${ }^{66}$ The relatively deprived families in rural China increase their spending on hosting funerals and wedding ceremonies (especially for grooms' families) as local competition for status intensifies. ${ }^{67}$ The relatively deprived households spend much higher budget on gifts and festivals in rural China, accounting for some of the large and escalating household spending on major ceremonies. ${ }^{68}$ The gifts received when hosting these costly ceremonies are often barely enough to cover wasteful status games. ${ }^{69}$

Perhaps due to the richer context in urban China, there is no evidence of status seeking squeezing out subsistence consumption (including cereals, cakes, fish, beverages, and restaurant orders). However, studies in the rural context find that gift and festival spending due to status concern and RD feelings squeezes out basic food consumption. ${ }^{70}$

\footnotetext{
${ }^{64}$ Sun and Wang. Do relative income and income inequality affect consumption? 1-14.

${ }^{65}$ The New York Times. China Curbs Fancy Tombs That Irk Poor. April 22, 2011.

${ }^{66}$ The Foreign Policy. Bachelor Padding. September 28, 2012.

${ }^{67}$ Brown et al. Positional spending and status seeking in rural China. 139-149.

${ }^{68}$ Chen, X., R. Kanbur. and X. Zhang. Peer effects, risk pooling, and status seeking: what explains gift spending escalation in rural China? CEPR Discussion Papers 8777, 2012.

${ }^{69}$ Chen X. Gift Escalation and Network Structure in Rural China. PLoS ONE. 9(8) (2014): e102104.

${ }^{70}$ Chen and Zhang. Costly posturing.
} 


\section{Economic and Policy Implications}

Existing studies on status concern and RD in China concentrate on three aspects - economic behavior, health, and happiness. In the following discussions, I relate their empirical findings to economic meanings and discuss their implications for public policies, including , and relative poverty alleviation. The first two types of policies, i.e. redistributive tax policies (section 4.1) and regulations and community sanctions (section 4.2), directly correct micro level behavior inefficiencies, especially among the poor who consume more positional goods at the cost of cutting basic non-positional goods and therefore giving up real benefits. To the contrary, the third type of policies balancing economic efficiency and equity (section 4.3) mainly address macroeconomic inefficiencies. However, all these types of policy instruments are aimed at reducing $\mathrm{RD}$, which may effectively improve health and happiness, and mitigate behavior inefficiencies.

\subsection{Pigouvian Taxes and Conspicuous Consumption}

High status is often associated with large pecuniary and non-pecuniary benefits. To improve social status, people often signal accumulated wealth or education attainment. Top earners spend lavishly on conspicuous consumption. This ostentatious spending shifts the frame of reference for those below them in social status, inducing them to mimic high spenders and signal fictitious wealth and social status through large positional spending. Given underdeveloped credit market for the poor in China, they have to save for positional consumption and cut non-positional goods consumption. When income inequality worsens, the benefit gap between the high-status and lowstatus groups widens and the entry wealth level for the high-status group increases, which in turn strengthens saving incentives to increase positional consumption, typically on housing, and reduces non-positional consumption.

Status concern and $\mathrm{RD}$ also raise the importance of social inclusion, which incurs large expenditure among the poor. ${ }^{71}$ For example, high spending on gifts and festivals among the poor serves essential social roles, and the consequences of refusing to participate are grave. ${ }^{72}$

\footnotetext{
${ }^{71}$ Ravallion, M. and S. Chen. Weakly relative poverty. Review of Economics and Statistics. 93(4) (2011): 12511261.

${ }^{72}$ Banerjee, A. V. and E. Duflo. The economic lives of the poor. Journal of Economic Perspectives. 21(1) (2007): 141-167.
} 
Evidence from China has shown that the poor could spend more on basic food instead of festivals but failed to do so. Studies shed some light on the "food puzzle" raised by Angus Deaton as to why the nutritional status of the poor tends to be stagnant amid rapid income growth in developing countries. ${ }^{73} 74$

Given the clear evidence that positional spending among poor people squeezes their basic consumption, threatens their subsistence, and brings long-term unintended consequences to future generations, policies are needed that discourage positional consumption among the extremely poor without discriminating against the poor.

Pigouvian taxes on positional consumption may be a less intrusive means to curb wasteful statusseeking activities, promote basic goods consumption, and correct the distortion imposed by the negative externalities of positional spending. More specifically, visibility-based consumption taxes, similar to the luxury tax, can be imposed in proportion to how visible a consumption item is. For example, in the literature telephone surveys have been used to gauge the visibility of a comprehensive list of commodities. ${ }^{75}$ Such taxation has proved reliable and inexpensive in the United States and can be readily applicable to many other countries. The poorest segment of the population is expected to be the most responsive to such a tax.

More generally, redistributive policies, such as designing more progressive taxes, subsidizing basic education, financing public infrastructure, and providing universal basic health services, that seek to narrow gaps in income, wealth and opportunity, may make us better off by relieving the negative impact of RD on well-being. More progressive taxes imposed on status seeking activities (with negative externalities) can be used to finance the provision of public goods, such as education and infrastructure.

\subsection{Regulations and Grassroots Sanctions}

\footnotetext{
73 The popular explanation relates to the reductions in physical activities and the need for calories, but this alone is unable to explain why child malnutrition rate has barely improved.

${ }^{74}$ Chen and Zhang. Costly posturing.

${ }^{75}$ Heffetz, O. A test of conspicuous consumption: Visibility and income elasticities. Review of Economics and Statistics 93(4) (2011): 1101-1117.
} 
Positional spending among the poor can also be discouraged through official regulations and grassroots sanctions. For example, in the past few years China has cracked down on excessive official banqueting and gift giving in China ${ }^{76}$. Sales volumes of luxury cigarette and alcohol brands have reduced substantially, which helps cut booming governmental expenses that can be put into better uses for public services.

Meanwhile, social customs have been preserved in traditional Chinese society. For example, people spend lavishly on social ceremonies. Official regulations and grassroots sanctions targeting key players in social networks who organize such events may curb the zero-sum game of overspending on social parties and spill over to guests who contribute much to these events. In impoverished rural communities in central China, the recent ban on lavish ceremonies and high price alcohol and cigarette purchases by officials, who were often the most active in hosting such events and presenting gifts, effectively spills over to ordinary rural residents, who are punished by fellow villagers when they violate the regulations banning such activities for officials. ${ }^{77}$ Similar successful story is documented in central Asia’s Tajikistan where more than half the population lives in poverty. ${ }^{78}$ However, these policy instruments may be less feasible in developed countries where freedom of choice is highly valued.

\subsection{Policies Balancing Economic Efficiency and Equity}

Status concern and the feelings of RD highlight the classical trade-off between equity and efficiency. In the past three decades, China has placed economic growth (or economic efficiency) above redistribution (or socioeconomic equity) as its development priority. However, strong evidence of RD would indicate trade-offs for current growth promoting policies and cast serious doubt on the welfare justification that individuals always benefit from income promotion. ${ }^{79} \mathrm{RD}$ uniquely gauges this trade-off at the individual level, giving it an advantage over aggregate inequality measures such as the Gini index. Compared to aggregate inequality, $\mathrm{RD}$ is more sensitive to detecting the equity and efficiency trade-off. For example, in the case

\footnotetext{
76 The Economist. Two weddings, two funerals, no fridge. November 30, 2013.

${ }^{77}$ Caijing Magazine. Villages Regulate Banquets in China’s Hubei Province. October 14, 2014.

${ }^{78}$ National Public Radio. “Tajik government cracks down on wedding size.” February 16, 2008.

${ }^{79}$ Ravallion and Lokshin. Who cares about relative deprivation? 171-185.
} 
that economic growth leaves overall inequality unchanged, it is still likely that resources distribution within the society changes dramatically.

Placing emphasis solely on promoting economic growth without considering status concern and $\mathrm{RD}$ may not effectively improve well-being. For example, when economic growth leads to an unbalanced increase in individual income, the worsening RD among the poor will offset some of the welfare gains to them that result from higher absolute income. In the extreme case that relative income imposes counteracting impact (equal to the positive effect of own income) on well-being, an equal proportionate increase in all incomes may even leave average well-being unchanged. Similarly, promoting poverty reduction without considering the effects of a poor person's income gains on social comparators would entail welfare efficiency costs, as poor people face inefficiently high incentives to escape poverty without taking account of their negative spillover effect.

Any evaluation of poverty alleviation programs should make it clear what it means to be successful - reduced absolute poverty, reduced relative poverty, or both. Absolute poverty is the complete lack of resources to sustain life, while relative poverty refers to inadequate resources necessary to maintain the average standard of living in their society. As such, relative poverty implies that the individual has the ability to sustain own basic needs but may lack the resources to afford socially desirable goods or engage in social activities.

Government agencies should consider monitoring the impact of anti-poverty efforts using a relative poverty line that rises with per capita income or consumption. Relative poverty lines for more than 100 countries released by the World Bank provide such a reference for China. ${ }^{80}$ While economic growth in China has been accompanied by massive decline in the incidence of absolute poverty as the number of people who are absolutely poor has reduced significantly in recent decades, the number of people who are relatively poor has not changed much as inequality persists. The two trends imply a salient increase in the number of people who are not absolutely poor but are relatively poor (Figure 1). Due to the concern that the World Bank multi-country relative poverty line set at the socially acceptable level can still be very different among different

${ }^{80}$ Ravallion and Chen. Weakly relative poverty. 1251-1261. 
people even in a same country, another prevalent and more objective measure of relative poverty, the ratio of average income of the richest 20 percent to the poorest 20 percent gauged by the United Nations Development Program (UNDP), is reported in Figure 2. Comparing all 17 representative countries in 2013, China is among the highest, i.e. the richest 20 percent people on average earn more than 10 times as much as the poorest 20 percent people do. 


\section{Conclusions and Discussion}

A growing literature suggests that status concern and the feelings of RD lower both objective and subjective measures of well-being, as indicated by health and happiness, respectively. Motivated by status concern and RD, basic consumption, especially among the poor, has shown evidence of being squeezed to increase conspicuous consumption. RD complements absolute poverty measures. While the incidence of absolute poverty has been greatly declining in China, relative poverty has not been reduced as much due to the rising cost of maintaining social standard of living.

Alleviating RD through effective public policy instruments has the potential to relieve its wide range of negative impacts. Redistributive policies, such as a visibility-based consumption tax, may reduce positional spending activities and the feelings of $\mathrm{RD}$ among the poor. The redistributed resources can be used to finance public infrastructure, basic education, and universal basic health insurance that further promote equity. Besides, traditional community sanctions and official regulations targeting key players of social spending activities in the networks have proved to be successful in some less-developed contexts. Grassroots groups in China have also reacted positively to regulations mandating cuts in positional spending among local officials.

The remaining gaps in knowledge about the relationship between $\mathrm{RD}$ and individual well-being deserve future investigations. First, few results are directly comparable across studies in Table 1 because of differences in model specifications, choices of $\mathrm{RD}$ indicators, reference group definitions, estimators chosen, types of data, and so on. Meanwhile, individuals often choose to interact with people who are similar to them. This selection may simultaneously affect RD and individual well-being and make findings less generalizable to a larger population. Moreover, adaptation and changing aspirations may mediate the impact of relative deprivation on individual well-being. For example, people with more severe feelings of RD may adapt better to low status and form higher expectations about future status based on higher reference incomes. Ignoring such psychological factors may underestimate the negative effect of RD. Furthermore, most studies simply impose reference groups rather than asking individuals who their reference groups are. These constructed reference groups may pick up effects other than social comparison. For 
example, average income by geographic area might also measure local public goods provision, which confounds the negative impact of RD on well-being.

This review is restricted to studies in China that measure RD of economic resources, such as income, consumption and wealth, and identify its influences over individual behavior and wellbeing. However, RD describes a wider spectrum of feelings of deprivation, involving economic, political and social deprivation in multiple fields of social sciences. For example, status and feelings of RD can be determined by individual rights of expression and community engagement, which in turn aggravate social exclusion and lack of expression of right. Social scientists, particularly political scientists and sociologists, document such RD as a major cause of social deviance, such as illegal timber cutting and crime in China ${ }^{81}{ }^{82}$, due to the discontent and frustration people experience when they feel they do not receive a "fair share" of something they deserve but others already have. Another intriguing body of empirical studies in other countries suggests that RD predicts risks of social unrest and may lead to political violence. Overall, monitoring RD may help governments identify such risks of social deviance and even social unrest at an early stage and take effective measures to reduce tensions. Governments could define a threshold RD level above which automatic emergency measures are triggered.

Finally, due to the multidimensional feature of status concern and feelings of RD, it is important to know where the dominant RD originates, such as gaps in income, wealth, consumption, title, appearance, social capital in the society, or rights of expression. Policies that address certain aspects of RD may lead to other inequalities becoming the more important source of RD.

\footnotetext{
81 Zackey, J. Peasant Perspectives on Deforestation in Southwest China. Mountain Research and Development 27(2) (2007):153-161.

${ }^{82}$ Chen, TS. and Y. Wu. Crime rates and inequality: a study of crime in contemporary China. Journal of the Asia Pacific Economy 20(2) (2014): 202-223.
} 


\section{Reference}

Appleton, S. and Song, L. 2008. Life satisfaction in urban China: Components and Determinants. World Development 36: 2325-2340.

Ball, Sheryl B. and Catherine C. Eckel. 1996. Buying Status: Experimental Evidence on Status in Negotiation. Psychology and Marketing 13(4): 381-405.

Banerjee, A. V. and E. Duflo. 2007. The economic lives of the poor. Journal of Economic Perspectives. 21(1): 141-167.

Brockmann, H., Delhey, J., Christian, W. and Yuan, H. 2009. The China puzzle: Falling happiness in a rising economy. Journal of Happiness Studies 10(4): 387-405.

Brown, P., E. Bulte. and X. Zhang. 2011. Positional spending and status seeking in rural China. Journal of Development Economics. 96(1): 139-149.

Cai, Fang and Yang. Du. 2002. Two Incentives of Migration and Their Policy Implication: Examine the Relative Deprivation Theory. Journal of Population Science. 2002: 4

Carlsson, F. and P. Qin. 2010. It is better to be the head of a chicken than the tail of a phoenix: Concern for relative standing in rural China, The Journal of Socio-Economics. 39(2): 180-186. Chang, Simon and Zhang, Xiaobo, 2012. The Economic Consequences of Excess Men: Evidence from a Natural Experiment in Taiwan. IFPRI discussion papers 1203.

Chen, X. 2014. Award Winning Papers: Essays on Relative Concerns, Social Interactions, and Unintended Consequences. Forthcoming in American Journal of Agricultural Economics. Chen, X. and X. Zhang. 2012. Costly posturing: relative status, ceremonies and early child development in China. World Institute for Development Economic Research (UNU-WIDER) Research Working Paper No. 2012/70.

Chen, X., R. Kanbur. and X. Zhang. 2012. Peer effects, risk pooling, and status seeking: what explains gift spending escalation in rural China? CEPR Discussion Papers 8777.

Clark, A.E., Frijters, P. and Shields, M. 2008. Relative income, happiness and utility: An explanation for the Easterlin paradox and other puzzles. Journal of Economic Literature 46(1): 95-144.

Cooper, B., C. Garcia-Penalosa. and P. Funk. 2001. Status effects and negative utility growth. Economic Journal. 111: 642-665.

Deaton, A. 2001. Relative deprivation, inequality, and mortality. NBER Working Paper 8099. 
Duesenberry, J.S., 1949. Income, Saving and the Theory of Consumer Behavior. Harvard University Press, Cambridge, MA.

Easterlin, R. 1974. Does economic growth improve the human lot? Some empirical evidence. In Nations and Households in Economic Growth: Essays in Honor of Moses Abramovitz, ed. R. David and M. Reder. New York: Academic Press, 89-125.

Easterlin, R. 2001. Income and happiness: towards a unified theory. Economic Journal 111: 465-484.

Frank R.H. 1985. The demand for unobservable and other non-positional goods. American Economic Review 75: 101- 116.

Frank, R.H., 1999. Luxury Fever: Why Money Fails to Satisfy in an Era of Excess. Free Press, New York.

Gerdtham, Ulf-G. and M. Johannesson. 2004. Absolute income, relative income, income inequality, and mortality. Journal of Human Resources. 39 (1): 228-248.

Huberman, Bernardo A., Christoph H. Loch, and Ayse Önçüler. 2004. Status as a Valued Resource. Social Psychology Quarterly. 67(1): 103-114.

Knight, John. and Gunatilaka, Ramani, 2012. Income, aspirations and the Hedonic Treadmill in a poor society. Journal of Economic Behavior \& Organization. 82(1): 67-81.

Knight, J., L. Song. and R. Gunatilaka. 2009. Subjective well-being and its determinants in rural China. China Economic Review. 20(4): 635-649.

Li, H. and Y. Zhu. 2006. Income, income inequality, and health: Evidence from China. Journal of Comparative Economics. 34(4): 668-693.

Ling, D. 2009. Do the Chinese 'keep up with the joneses'? implications of growing economic disparities and relative deprivation on health outcomes among older adults in China. China Economic Review. 20(1): 65-81.

Mangyo, E. and A. Park. 2011. Relative deprivation and health: Which reference groups matter? Journal of Human Resources 46(3): 459-481.

Marmot, Michael G., Davey-Smith, George, et al. 1991. Health inequalities among British civil servants: The Whitehall II study. Lancet. 337 (8754): 1387-1393.

Oshio, T, Nozaki, K. and Kobayashi, M. 2011. Relative Income and happiness in Asia: Evidence from nationwide surveys in China, Japan and Korea. Social Indicators Research 104, 351-367. 
Ravallion, M. and S. Chen. 2011. Weakly relative poverty. Review of Economics and Statistics. 93(4): 1251-1261.

Ravallion, M. and M. Lokshin. 2010. Who cares about relative deprivation? Journal of Economic Behavior \& Organization. 73(2): 171-185.

Runciman, W.G., 1966. Relative Deprivation and Social Justice. Routledge and Kegan Paul, London.

Stark, O. and S. Yitzhaki. 1988. Labor migration as a response to relative deprivation. Journal of Population Economics. 1 (1): 57-70.

Sun, W. and X. Wang. 2012. Do relative income and income inequality affect consumption? Evidence from the villages of rural China. Journal of Development Studies. 1-14.

Tao, H. and Chiu, S. 2009. The effects of relative income and absolute income on happiness. Review of Development Economics 13(1): 164-174.

Verme, P. 2010. Happiness, Deprivation and the Alter Ego, in The Measurement of Individual Well-being and Group Inequalities Essays in Memory of Z. M. Berrebi. Deutsch, J. and Silber, J. (Eds.), Routledge.

Veblen, Thorstein. 1899. The Theory of the Leisure Class. Reprint 1965, MacMillan: New York. Wang, P. and Vander Weele, T.J. 2011. Empirical Research on Factors Related to the Subjective Well-being of Chinese Urban Residents. Social Indicators Research 101, 447-459.

Wei, Shang-Jin and Xiaobo Zhang. 2011. Sex Ratios, Entrepreneurship, and Economic Growth in the People's Republic of China. NBER Working Papers 16800.

Wildman, J. 2003a. Modeling health, income and income inequality: The impact of income inequality on health and health inequality. Journal of Health Economics. 22, 521-538.

Wildman, J. 2003b. Income related inequalities in mental health in Great Britain: Analyzing the causes of health inequality over time. Journal of Health Economics. 22, 295-312.

Yitzhaki, S. 1979. Relative deprivation and the Gini coefficient. Quarterly Journal of Economics. 93(2): 321-24. 
Figure 1 Number of Absolutely Poor People and Relatively Poor People in China, 1981-2008

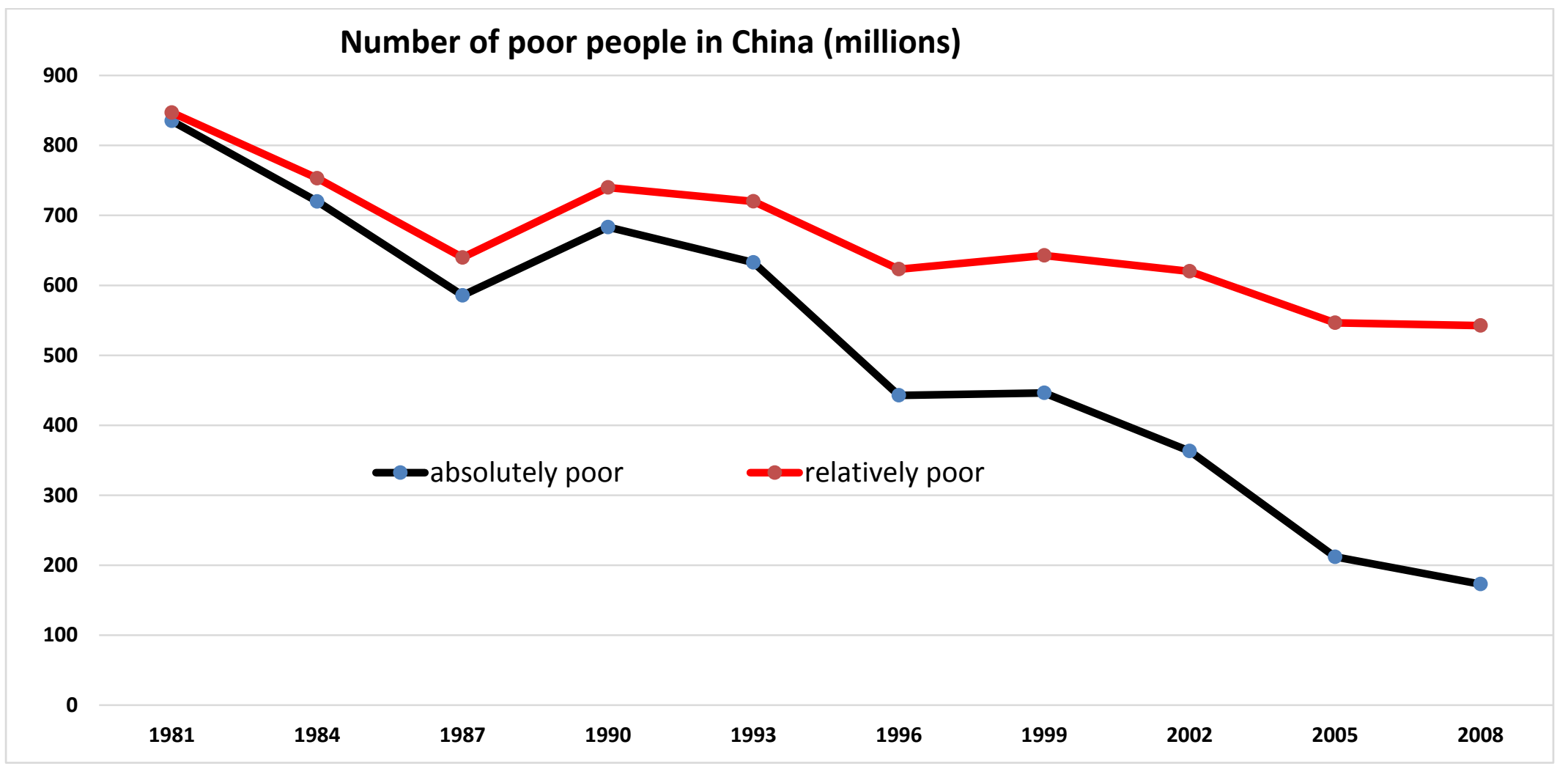

Note: Absolutely poor is defined as an income of less than $\$ 1.25$ a day at the 2005 purchasing power parity. According to the relative poverty line set by the World Bank for more than 100 countries, those relatively poor refer to people with incomes below a socially acceptable level, which is often higher than the absolute poverty line. Refer to the World Bank http://elibrary.worldbank.org/doi/pdf/10.1596/1813-9450-6114 for the data used here. 
Figure 2 Relative Poverty across Countries: The ratio of Average Income of the Richest $20 \%$ to the poorest $20 \%, 2013$

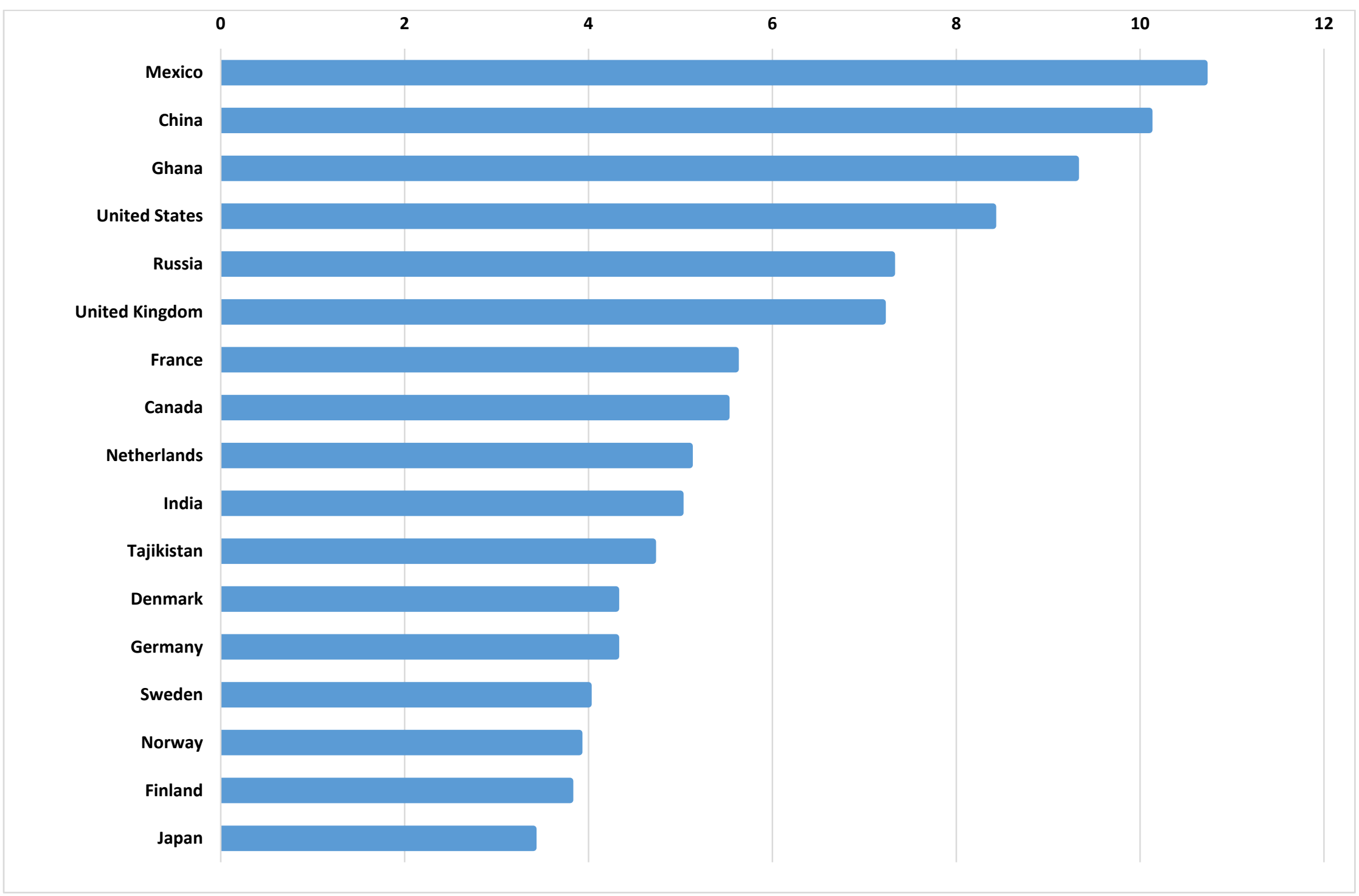

Note: United Nations Development Program (UNDP) 2013 data. Online at: http://hdr.undp.org/en/content/income-quintile-ratio 
Table 1 Empirical Evidence on Status Concern and Feelings of RD in China

\begin{tabular}{|c|c|c|c|}
\hline Paper & Source of variation; RD measures & Data and sample size & Magnitude of RD impact \\
\hline \multicolumn{4}{|c|}{ Evidence on Happiness } \\
\hline $\begin{array}{l}\text { Knight et al. } \\
\text { (2009) }\end{array}$ & $\begin{array}{l}\text { Own income relative to village } \\
\text { average income (subjective) }\end{array}$ & $\begin{array}{l}2002 \text { national household } \\
\text { survey of 9,200 households } \\
\text { in rural China }\end{array}$ & $\begin{array}{l}\text { Relative income is at least twice as important for individual } \\
\text { happiness as actual income. Controlling for individual income, } \\
\text { having "income much below average in the village" decreases } \\
\text { happiness by } 1 \text { standard deviation compared to those with "income at } \\
\text { the village average". }\end{array}$ \\
\hline $\begin{array}{l}\text { Appleton and } \\
\text { Song (2008) }\end{array}$ & Individual level RD measures & $\begin{array}{l}7000 \text { respondents from the } \\
2002 \text { urban survey of the } \\
\text { Chinese Household Income } \\
\text { Project (CHIP) }\end{array}$ & $\begin{array}{l}\text { A one-unit increase in satisfaction with income compared with the } \\
\text { people one knows promotes one's overall life satisfaction by } .075 \\
\text { point (on a } 1-5 \text { scale). Meanwhile, a one-unit increase in satisfaction } \\
\text { with current social status increases one's overall life satisfaction } \\
\text { by } .049 \text { point (again, on a } 1-5 \text { scale). }\end{array}$ \\
\hline $\begin{array}{l}\text { Knight and } \\
\text { Gunatilaka } \\
\text { (2012) }\end{array}$ & $\begin{array}{l}\text { Own income relative to village } \\
\text { average income (subjective) }\end{array}$ & $\begin{array}{l}2002 \text { national household } \\
\text { survey of 9,500 households } \\
\text { in rural China }\end{array}$ & $\begin{array}{l}\text { Controlling for individual income and income aspiration, having } \\
\text { "income much below village average" decreases satisfaction with life } \\
\text { by .794 point (on a 1-5 scale) compared to those with "income at the } \\
\text { village average". Having "income much below village average" } \\
\text { decreases satisfaction with income by .809 point (on a 1-5 scale) } \\
\text { compared to those with "income at the village average". }\end{array}$ \\
\hline $\begin{array}{l}\text { Oshio et al. } \\
\text { (2011) }\end{array}$ & $\begin{array}{l}\text { Difference between individual or } \\
\text { family income of the respondent and } \\
\text { its average within the reference } \\
\text { group. }\end{array}$ & $\begin{array}{l}2726 \text { respondents in } 2006 \\
\text { China General Social } \\
\text { Surveys (CGSS) }\end{array}$ & $\begin{array}{l}\text { A one unit increase in the difference between log individual income } \\
\text { and log peers' average income is associated with .196 - .253 point (on } \\
\text { a 1-3 scale) increase in perceived happiness or life satisfaction, } \\
\text { depending on model specifications. }\end{array}$ \\
\hline $\begin{array}{l}\text { Wang and } \\
\text { VanderWeele } \\
(2011)\end{array}$ & $\begin{array}{l}\text { Individual level RD index composed } \\
\text { of three aspects of comparison of } \\
\text { own quality of life with (i) their } \\
\text { peers, (ii) themselves } 3 \text { years ago, } \\
\text { and (iii) the normal people in their } \\
\text { eyes. }\end{array}$ & $\begin{array}{l}5894 \text { urban respondents in } \\
2003 \text { China General Social } \\
\text { Surveys (CGSS) }\end{array}$ & $\begin{array}{l}\text { The log probability of higher subjective well-being is increased by } \\
49 \% \text { for individuals with a RD score that is one level higher, i.e. who } \\
\text { feel less RD, on a } 0-9 \text { scale. }\end{array}$ \\
\hline $\begin{array}{l}\text { Tao and Chiu } \\
\text { (2009) }\end{array}$ & $\begin{array}{l}\text { Individual level measures of average } \\
\text { income in the reference group }\end{array}$ & $\begin{array}{l}1277 \text { individuals from the } \\
2001 \text { Taiwan Social Change } \\
\text { Survey }\end{array}$ & $\begin{array}{l}\text { One unit (NT\$10,000) increase in income of all people in the } \\
\text { economy reduces happiness by } .893 \text { points (on a 1-4 scale) as a result } \\
\text { of the relative income effect. The negative relative income effect } \\
\text { almost countervails the positive absolute income effect, suggesting } \\
\text { the importance of RD. }\end{array}$ \\
\hline
\end{tabular}




\begin{tabular}{|c|c|c|c|}
\hline \multicolumn{4}{|c|}{ Evidence on Health } \\
\hline $\begin{array}{l}\text { Mangyo and } \\
\text { Park (2011) }\end{array}$ & $\begin{array}{l}\text { Own income relative to } \\
\text { relatives/classmates/neighbors } \\
\text { average income (subjective); mean } \\
\text { per capita income within } \\
\text { township/county/province } \\
\text { (objective) }\end{array}$ & $\begin{array}{l}\text { 2004 China Inequality and } \\
\text { Distributive Justice Survey, } \\
\text { nationally representative } \\
\text { sample of 3,267 Chinese } \\
\text { adults in rural and urban } \\
\text { China }\end{array}$ & $\begin{array}{l}\text { A one-rank increase in relative living standards in comparison to } \\
\text { relatives/classmates/neighbors increases self-reported happiness and } \\
\text { SRHS by } 0.163-0.182 \text { standard deviations and improves } \\
\text { psychosocial health by } 0.096-0.128 \text { standard deviations. }\end{array}$ \\
\hline $\begin{array}{l}\text { Li and Zhu } \\
\text { (2006) }\end{array}$ & $\begin{array}{l}\text { Temporal changes in both } \\
\text { community level inequality } \\
\text { measures and individual level RD } \\
\text { measures }\end{array}$ & $\begin{array}{l}7286 \text { individuals from four } \\
\text { waves of China Health and } \\
\text { Nutrition Survey between } \\
1991 \text { and } 2000\end{array}$ & $\begin{array}{l}\text { SRHS, heart function and ADL nonlinearly decrease with inequality } \\
\text { for Gini coefficient larger than } 0.42 \text { and } 0.29 \text {, respectively. A rise in } \\
\text { the Gini by } 1 \text { standard deviation increases the probability of drinking } \\
\text { alcohol and smoking by } 1.8 \text { and } 2.1 \text { percentage points, respectively. } \\
\text { However, the negative impacts of income inequality on SRHS, heart } \\
\text { function and ADL do not vary by relative income or rank. None of } \\
\text { RDA, RDI or rank is significantly associated with SRHS, heart } \\
\text { function and ADL. }\end{array}$ \\
\hline Ling (2009) & $\begin{array}{l}\text { Temporal changes in both } \\
\text { community level inequality } \\
\text { measures and individual level RD } \\
\text { measures }\end{array}$ & $\begin{array}{l}3164 \text { respondents above age } \\
50 \text { from six waves of China } \\
\text { Health and Nutrition } \\
\text { Survey between } 1989 \text { and } \\
2004\end{array}$ & $\begin{array}{l}\text { Inequality measured by Gini does not explain health outcomes and } \\
\text { health behavior except high waist circumference. Measured by } \\
\text { Deaton RD, an increase in RD lowers the probability of having high } \\
\text { waist circumference by } 65.9 \text { percentage points, increases } 0.1 \text { day's } \\
\text { worth of nutritional intake, reduces the probability of being } \\
\text { overweight by } 53.4 \text { percentage points, and raises their probability of } \\
\text { ever smoking cigarettes by } 132.9 \text { percentage points. }\end{array}$ \\
\hline $\begin{array}{l}\text { Chen and } \\
\text { Zhang (2012) }\end{array}$ & $\begin{array}{l}\text { Temporal changes in individual level } \\
\text { Deaton RD measure }\end{array}$ & $\begin{array}{l}260 \text { children age between } 0 \text { - } \\
5 \text { born to } 900 \text { households in } \\
\text { rural Guizhou province } \\
\text { during 2004-2009 }\end{array}$ & $\begin{array}{l}\text { Doubling the number of prenatal exposures to social ceremonies in a } \\
\text { village would lower the height-for-age z-score of children born to the } \\
\text { lower half families by } 0.54 \text { standard deviations and raise their } \\
\text { stunting rate by } 0.48 \text { standard deviations. The more relatively } \\
\text { deprived the household, the higher marginal detrimental effect there } \\
\text { is to its child health outcomes. }\end{array}$ \\
\hline
\end{tabular}




\begin{tabular}{|c|c|c|c|}
\hline \multicolumn{4}{|c|}{ Evidence on Behavior } \\
\hline $\begin{array}{l}\text { Jin et al. } \\
\text { (2011) }\end{array}$ & $\begin{array}{l}\text { Temporal changes in community and } \\
\text { age cohort inequality measures }\end{array}$ & $\begin{array}{l}102,971 \text { households in } \\
\text { China Urban Household } \\
\text { Survey data during 1997- } \\
2006\end{array}$ & $\begin{array}{l}\text { In the sample the Gini coefficient rose from } 0.23 \text { to } 0.29 \text { from } 1997 \\
\text { to } 2006 \text {, implying a decline of the average propensity to consume by } \\
2.08 \text { percentage points and rising education expenditures by } 30.4 \% \text {. }\end{array}$ \\
\hline $\begin{array}{l}\text { Sun and Wang } \\
\text { (2012) }\end{array}$ & $\begin{array}{l}\text { Temporal changes in individual level } \\
\text { RD measures }\end{array}$ & $\begin{array}{l}69089 \text { households surveyed } \\
\text { between } 2003 \text { and } 2006 \text { by } \\
\text { Research Centre on the } \\
\text { Rural Economy (RCRE), } \\
\text { Ministry of Agriculture }\end{array}$ & $\begin{array}{l}\text { A ten percentile drop in permanent income rank is associated with } \\
7 \% \text { higher overall consumption rate. A } 0.1 \text { increase in Deaton RD } \\
\text { corresponds to } 12 \% \text { higher overall consumption rate. RD imposes the } \\
\text { positive impacts on positional consumption in the following order: } \\
\text { clothing>housing>eating out>education. }\end{array}$ \\
\hline $\begin{array}{l}\text { Brown et al. } \\
\text { (2011) }\end{array}$ & $\begin{array}{l}\text { Temporal changes in higher order } \\
\text { community level income distribution } \\
\text { measures }\end{array}$ & $\begin{array}{l}900 \text { households from rural } \\
\text { Guizhou province during } \\
\text { 2004-2009 }\end{array}$ & $\begin{array}{l}\text { For the poorest } 25 \% \text { households, a } 1 \text {-unit rise in kurtosis increases } \\
\text { funeral expenses by } 2 \% \text {. Meanwhile, a } 1 \text {-unit rises in skewness and } \\
\text { kurtosis increase wedding expenses paid by the groom's family by } \\
14.9 \% \text { and } 2.4 \% \text {, respectively. }\end{array}$ \\
\hline $\begin{array}{l}\text { Chen et al. } \\
\text { (2012) }\end{array}$ & $\begin{array}{l}\text { Temporal changes in individual level } \\
\text { RD measures }\end{array}$ & $\begin{array}{l}\text { 8,074 pairwise gift links } \\
\text { between } 335 \text { households in } \\
\text { rural Guizhou province } \\
\text { during 2000-2009 }\end{array}$ & $\begin{array}{l}\text { Measured by Deaton RD, the lowest-ranked households spend 13.5- } \\
56.7 \text { percent more on gift giving per occasion than do top households, } \\
\text { depending on model specifications. Moreover, households at the } \\
\text { bottom of income distribution experience } 75-85 \text { percent higher } \\
\text { increase in gift spending per occasion than do top households, } \\
\text { depending on model specifications. }\end{array}$ \\
\hline
\end{tabular}

